Marquette University

e-Publications@Marquette

College of Nursing Faculty Research and

Publications

Nursing, College of

$11-1-2004$

\title{
Conducting Life History Research With Adolescents
}

Kristin Haglund

Marquette University, kristin.haglund@marquette.edu

Accepted version. Qualitative Health Research, Vol. 14, No. 9 (November 2004): 1309-1319. DOI. (C) 2004 SAGE Publications. Used with permission. 


\section{Conducting Life History Research With Adolescents}

By Kristin Haglund

This article is a commentary on the life history approach, which specifically described aspects of and offered suggestions for conducting life history research with adolescents. The life history approach is well suited to a wide variety of types of health-related inquiry. In this article, the author used an exemplar study to show how well the life history approach was suited for questions regarding adolescent issues. This approach was also a good match for the developmental skills and needs of adolescents. The author uses the strengths and weaknesses of the approach and a detailed example of how she used the life history data to identify themes drawn from the exemplar study. She makes specific suggestions, including the development and implementation of an interview guide, planning and scheduling interviews, and the use of a life history grid. She includes examples of each suggestion and a sample life history grid.

The life history approach is well suited for inquiry in a wide variety of psychosocial phenomena. The approach incorporates core values shared by health care professionals, including recognition of the agency of each individual and the essential role of context in the living of a life. It is a holistic, dynamic process incorporating the participants' retrospective life experiences and the researcher's interpretations (Admi, 1995). Many psychosocial phenomena do not occur spontaneously; rather, they develop over time in response to a wide variety of influences. The life history method facilitates study of such phenomena, because the researcher obtains lifelong data, allowing him or her to explore a variety of experiences and relationships and to examine changes over time. Life history researchers recognize the participants as collaborative partners, involved in exploration, discovery, and understanding. The participants actively remember and reconstruct their lives through the telling of their stories. The researcher guides the participant through his or her life history, prompting memories and encouraging the participant's reflections, interpretations, and insights. This approach yields data that help researchers gain insights into how past events and relationships might influence current phenomena and how human beings understand their lives (Haglund, 2003; Sandelowski, 1991). Understanding the experiences of other human beings facilitates understanding of the broader human condition (Cole \& Knowles, 2001).

To gain an understanding of a human being's life, one needs an in-depth understanding of the context within which that person's life is situated (Cole \& Knowles, 2001). Context is the ubiquitous backdrop that influences how a life is lived and interpreted. Context informs one's Haglund 1 
worldview, through which events, thoughts, experiences, and relationships are filtered and assigned meaning. Context is not the unit of analysis in life history research but is critical to the eventual understanding of a life, an event within a life, or a particular experience. Data generated by the life history approach are characterized by the richness and complexity of contextual information (Cole \& Knowles, 2001).

Other authors have published recommendations and instructions on how to use the life history approach (Admi, 1995; Cole \& Knowles, 2001; Hagemaster, 1992; Sandelowski, 1991). In this article, I describe the use of the life history method with adolescents. My purpose is to demonstrate how the life history approach facilitates understanding of psychosocial phenomena, to demonstrate that adolescents have enough life experiences to describe a meaningful life history, and to provide specific recommendations for using this approach with adolescents. This article might be of interest to researchers who study psychosocial phenomena in adolescents and have not considered lifelong data, to those researchers who use the life history method with other age groups but are concerned that it might not work with youth, or to those who are already planning to use the life history approach with youth. Idrew examples and recommendations from an earlier study (Haglund, 2003). In the brief description of this study, I illustrate how I selected the life history approach and demonstrate how the approach facilitated the discovery of themes.

\section{Description of the Exemplar Study}

The purposes of this study were to generate an understanding of the experience of adolescent sexual abstinence including a teen-centered description of abstinence and descriptive information about the ways in which various life contexts supported and inhibited it. This study was framed by a conceptual perspective, the life span developmental approach (Smith \& Baltes, 1999). In Smith and Baltes's view, human development is a lifelong, dynamic process of growth, loss, and change that is influenced by context and varies among individuals. Applying the life span perspective to this study, I assumed sexual abstinence to be a developmental phenomenon, a state of being that had progressed over time in accordance with the biological processes of growth and maturity and that a variety of contexts had influenced. To discover how abstinence developed over time, I determined that lifelong data were required. Asking young women about their current states of being without exploring their pasts and their futures would have been inadequate. Therefore, the life history approach appeared to be the ideal means to collect a broad, comprehensive data field from which I might eventually glean understanding about the lives of sexually abstinent youth. 
The data were rich and copious, allowing elements that were not immediately apparent to the participant and were surprising to me to be included and eventually identified. For example, had I focused the interview on their current state of abstinence, the participants would have offered data that they thought pertained to being abstinent. Experiences or events that were influential to their status as abstinent might have gone unsaid if they had not noted the connection themselves, had forgotten about it, or, for whatever reason, did not share the information. Thus, the life history approach was well suited to this study, which included a developmental perspective and was designed to elucidate descriptive information about a psychosocial phenomenon.

I analyzed data by using a modified type of narrative analysis (Polanyi, 1989). I divided transcripts into narratives, then condensed them into adequate paraphrases. The elements of each narrative that the participants emphasized most heavily formed the adequate paraphrases. I entered the paraphrases into NVivo and coded them, eventually revealing themes related to descriptions of sexual abstinence and to contextual influences of sexual abstinence.

The life history approach was critical for identification of the themes of this study, including the theme of mothers and maternal grandmothers as role models of adult women. The participants viewed their mothers and maternal grandmothers as women who were strong, responsible, and mature. They were women who worked hard to keep their families together and safe. The participants maintained sexual abstinence to demonstrate that they were becoming mature women like their mothers and grandmothers.

Questions about maternal grandmothers in the present generally elicited brief responses. Some said that she had passed away; others described visits and gifts from their grandmothers. It was not until they were asked about their early childhoods that the grandmothers' role as a safety net became clear. She had provided vital support that allowed the participants, their mothers, and siblings, if there were any, to stay together in a home where their basic needs, such as nutrition and safety, were met. For example, some of the participants lived with their maternal grandmothers when they were infants and young children because their mothers were adolescents, the mother had escaped an abusive partner, or the family had lost everything in a house fire. In these instances, the maternal grandmother took the mother and her children in and supported them, thus keeping them together as a family. In some cases, the participants did not remember living with their grandmothers, although they knew that they did, and so they were not completely aware of how she had helped their family. Nonetheless, through their telling of their experiences of early childhood, the role of their maternal grandmothers was revealed. Now, most of the families were stable, and the grandmothers' role 
as safety net had been suspended. If the participants had not asked been about their early childhoods, this role of the maternal grandmother would not have been revealed.

The life histories were also critical to my understanding of the participants' relationships with their mothers. These relationships were important influences on their present abstinence. As mentioned earlier, mothers were influential role models of adult women. The life history data revealed how the participants' relationships with, and perceptions of, their mothers had changed as the participants matured. Most described a period in early adolescence when their relationship with their mother was strained. They talked about their feelings at that time and about how they argued with their mothers. Most then talked about how improved their relationships with their mothers were now and related those improvements to their own maturity. The participants identified that as they grew older, they came to recognize and admire their mothers' struggles and efforts to sustain their family. Their past experiences of living with their mothers, and witnessing and sharing their challenges shaped their current perception of themselves as soon-to-be-adult women. Again, the life history data was critical to understanding the participants' relationships over time with their mothers.

\section{Conducting Life Histories with Adolescents}

\section{Strengths}

The life history approach works well with adolescents. They have the necessary skills, including recall, insight, interest, and attention span to relate their histories. They also have had enough life experiences to conduct a meaningful 2-hour interview. For this study, the life history format was a useful way to organize the interviews, as the participants easily organized their experiences chronologically. During the recruitment and consent processes, the participants were informed that they would be asked to tell their life history from when they were born to the present. This information helped them to prepare in advance of their first interviewbyorganizing their memories into a "story of my life" format in which first this happened, then that. During the interviews, they responded thoughtfully to questions about their lives and appeared to be making some connections or insights as they related their stories. For example, one participant was talking about how she fought so much in middle school that the other students nicknamed her Mike Tyson. I asked if the nickname and attention made her feel good. A thoughtful look appeared on her face, and she said, "Yes, I think I did. When they used to say, 'What's up, Mike Tyson?' Or I heard somebody talking about me fighting ...I think I used to feel good."

The participants appeared to enjoy relating their life stories, saying at the close of some of the interviews that the process had been fun. Others reported feeling "honored" to participate Haglund 4 
in this study. They felt that by being asked to participate, they were being recognized for their virtue of being sexually abstinent. They also valued that their words and experiences would be used to help other teens.

\section{Weaknesses}

As one would expect, adolescents' memories of their early childhoods are less clear than their memories of their school-age and adolescent years. This might make it difficult to date early experiences, to track where families have lived and moved from, and to understand early household composition. When details of early memories are necessary, consider obtaining the participant's permission to interview the parent(s) or other relative who might have the missing details. In this study, some participants were unable to answer any questions regarding their infancy and early childhoods, including what state they had lived in or with whom they had lived. Others relied on second-hand history. For example, one participant responded to a question about where she lived as an infant with, "I don't remember but my mother told me that we lived in Chicago." Some participants made educated guesses about the circumstances of their early years, such as "After the fire we couldn't live at home so we must have lived with my grandmother." Although some remembered events or people from their early childhoods, these memories tended to be more general and lack specific details, such as addresses, dates, and their or others' ages. Some participants could describe the house they had lived in and even what the street looked like but could not remember the name of the street or the neighborhood in which they had lived. Age was often characterized as "when I was little" or "when I was in kindergarten" instead of referring to an actual age or year. Sometimes, milestones were referenced rather than ages or dates, such as "I was walking then" or "That was before my brother was born." The participants' memories became clearer and more detailed as they discussed things in the recent past and the present.

\section{Recommendations}

In this section, I will describe recommendations for using the life history approach specifically with adolescents. These recommendations address issues that are unique to adolescent participants, such as their need for parental consent for participation coupled with their concerns about confidentiality from parents; status discrepancies between the researcher and the participants in terms of age, wealth, or position coupled with the need to establish rapport and engagement; and logistical concerns, such as competition with the spontaneity of adolescents' schedules and their lack of transportation. The recommendations, summarized in 
Table 1, cover three areas: the development and use of interview guides, planning and scheduling interviews, and creation and use of a life history grid.

\section{Interview Guides}

A written interview guide is important. The guide can be shared with youth and parents during the consent process if there is concern about the type of questions that will be asked. Similarly, the guides are important during the process of obtaining institutional review board approval. Guides help to ensure that the inter-viewer(s) will ask similar questions of all participants. Designing questions that move in chronological order from birth to the present provides participants a logical outline to facilitate the telling of their stories. Include the contexts of life that are expected to be central to the life of an adolescent including school, family, peers, activities, self, and sexuality. Other contexts can be included based on the aims of the study. Include many follow-up questions, and be prepared with prompts. The young women in this study expected that the interviewer would ask them questions. They waited for a question, responded, and then waited for the next question. Some participants came to the interviews prepared to tell their life stories. These participants summarized their lives in a brief speech at the beginning of the interview and concluded with "That's my whole story, what else do you want to know?" They then waited for me to ask them questions. General open-ended questions about dreams, talents, hardships, and successes are also helpful in redirecting the participants or when the researcher is unsure of what to ask next. They also potentially introduce new topics for exploration and new perspectives on the participant's life.

Allow flexibility in the interview guide. Each participant had unique experiences, and often individualized follow-up questions and prompts were required to draw out a detailed description of the story. I also used specific questions for clarification because of some participants' styles of speech, unique word choices, or descriptions of things that were unfamiliar to me. Some participants, perhaps thinking that I was interested only in what happened, related stories that left out their emotional responses and their interpretations of the story, such as why the event came about, what it meant to them, or how it changed a relationship. Reassurance was required to convey that I was interested in the participant's interpretations and reflections. Then, the individualized prompts and questions were needed to draw forth this information. Researchers might need new questions as the interviews progress to explore emergent areas that were not included in the original guide or because the existing questions are not adequately eliciting the data needed to answer the research questions. For example, as I used the interview guide to collect data for this study, it became apparent that the

\section{Haglund 6}


questions did not adequately address how the participants described abstinence. I then refined the guide by adding additional questions, including how the participants described abstinence, their experiences of being abstinent, and barriers to abstinence that they had encountered.

\section{Planning Interviews}

Schedule interviews in person, if possible, and give the participants written appointment cards. Ideally, schedule the first interview at the time of obtaining informed consent. Schedule the second interview immediately after the first. Reminder phone calls the day before, and the day of, the interview are very helpful. Allow some cushion before and after the scheduled appointment time to accommodate participants who are early or late for their appointments. Plan for each interview to take about an hour. Multiple 1-hour interviews will allow enough time to obtain adequate data, will more easily fit into the adolescents' schedules, and will not exceed their attention spans.

To facilitate an adolescent's attendance at the interview, schedule the interview somewhere where the adolescent is planning to be. The researcher should go to the adolescent. For example, in this study, most interviews were conducted in a private exam room in the school nurse's office at two high schools during the participants' lunch hours or immediately after school. Access to youth during the school day can be arranged by meeting with the school principal in advance. Explain to the parents during the consent process where the interviews will take place. Interviews can also be conducted in private rooms at a community center, a church, or a primary care clinic. In this study, because I went to the adolescents, there were few scheduled interviews that the participant failed to attend. For interviews conducted after school, provide bus tickets, as the teens will miss their usual way home. When the adolescent is expected to come to the researcher, mail bus tickets to participants in advance of the interview. Alternatively, when meeting with a parent during the consent process, arrange for the parent to transport the participant to the interview.

Planning multiple interviews will allow the researcher to begin with questions that are the least personal and reserve more sensitive questions regarding topics such as sexuality, family discord, and drug and alcohol use for subsequent interviews. The first interview is a time for establishing rapport and trust. An adolescent might not be immediately comfortable discussing personal information with someone who is older than he or she is and perhaps of a different ethnic group, gender, or socioeconomic class. Thus, the first interview is an opportunity for the researcher to demonstrate that he or she respects and accepts the participants and their stories and that he or she will maintain confidentiality. Although informed consent should state that all

\section{Haglund 7}


data are confidential, some teens might fear that the researcher will divulge sensitive information to their parents. In this study, the participants' trust increased after the first interview, when I did not call their parents and their parents did not request information from me. It was apparent that the comfort level had increased in the second interview, as they spontaneously revealed more personal and private information, such as their or their parents' drug or alcohol use.

\section{Life History Grid}

I constructed a life history grid for each participant to help organize life events, correlate items of each participant's life history, and summarize the formal written record (Anderson \& Brown, 1980; Hagemaster, 1992). One might choose to complete the grid during the interview as a way of engaging and involving a participant. I attempted it in this study but found that it was too time consuming and distracted my attention from the participants. Thus, I completed the grids when listening to the interview tapes. The grid, as described by Anderson and Brown, was created on a large sheet of paper divided into columns. The left-hand column listed the year of life, with one row for each year of the participant's life. For this study, the remaining column headings included age, parents, siblings, geography, friends, school, activities, health/puberty, romance, and church. I entered pertinent information for each column category into the appropriate row based on the participant's age. Examples of information included in the parent column were marital status of parents at birth and age at which they divorced or remarried. The significant happenings of siblings, such as birth or diagnosis of chronic illness, were included in the Siblings column. Geography included the location of where they lived, such as street name, city, or state. The Friends column included lack of friends or significant changes in friendships, such as making new friends or losing old ones. The column labeled School included grade, information about achievements and significant events. Activities included organized activities in and out of school, work, and hobbies. Health/puberty included significant information about health, such as serious illnesses or injuries and information about puberty, such as menarche. The column labeled Romance included information about their romantic feelings, relationships, and experiences. Finally, the column labeled Church included significant events related to their religious beliefs or experiences, such as when they were baptized or saved.

I used the life history grids for identifying patterns of experiences to understand the stories the participants told about their lives. For example, Participant 2 said that she had a strained relationship with her mother that was now starting to get better. "Our relationship has gotten so [much] better ...me and my mom, we used to fight all the time. It used to be like that in

\section{Haglund 8}


6th grade." According to her life history grid, a portion of which is shown in Table 2, she was 11 in 6th grade. This was the time she said that the "drama started": Her birth father stopped calling her, and she started to fight more with her mom. She had her first period. Then, she failed 6th grade, which, she felt, happened because her teacher was racist. This constellation of events provided a context for her relationship with her mother. It was obvious that this was a stressful time in her life. The data from across the columns clarified the context for the strained relationship between the participant and her mother.

Completing the life history grids together might be a useful way of engaging the participant in the research process. The grids are also useful during analysis as a way of identifying life patterns in a concise format. In this study, all of the participants received a copy of their life history grid. Some of the grids were mailed and some delivered in person when the participant and I met by chance at the high school in which many of the interviews took place. The participants stated that they valued the grids; perhaps the receipt of a tangible product is a way to enhance the experience of being a research participant.

\section{Conclusion}

When seeking answers, insight, and understanding regarding health-related phenomena, selection of the life history approach might be an appropriate option. This approach provides access to contextual data that helps the participants and researchers develop an understanding of how and why things happened in the past and how that past might be affecting the present. The data gathered in the life history approach, including contextual data and the participants' interpretations and emotional responses, make it possible to achieve a depth of understanding that would be difficult to match with less rich data. The chronological nature of a life history provides a natural organizing framework for the large amount of data that are collected. The life history grid, as described in this article, is one useful tool to organize data concisely and visually.

The life history approach, in addition to being well suited to health-related inquiry, is also a good choice when working with adolescents. Adolescents have, for the most part, achieved formal operations and have the ability to think abstractly. Most adolescents enjoy exercising their new skills in abstraction by engaging in thoughtful, meaningful, and, sometimes, philosophical conversations. Adolescents are developmentally capable of participating in a life history study. As they develop their sense of identity as an adult, they often reject more childish ways of being. They begin to expect that they should and will have some part in choices and decisions that affect them. The collaborative nature of the life history method, in which the self- 
determination of the adolescent is openly respected, addresses their developmental need to be treated like adults. Finally, the idea that their contributions will eventually help others often appeals to their idealism and developing identity as contributing citizens of their communities.

\section{References}

Admi, H. (1995). The life history: Aviable approach to nursing research. Nursing Research, 44(3), 186-188.

Anderson, J., \& Brown, R. (1980). Life history grid for adolescents. Social Work, 25(4), 321-323.

Cole, A., \& Knowles, J. (Eds.). (2001). Lives in context the art of life history research. Walnut Creek, CA: Altamira.

Hagemaster, J. (1992). Life history: Aqualitative method of research. Journal of Advanced Nursing, 17, 11221128.

Haglund, K. (2003). Sexually abstinent African American adolescent females' descriptions of abstinence. Journal of Nursing Scholarship, 35(3), 231-236.

Polanyi, L. (1989). Telling the American story. Cambridge, MA: MIT Press.

Sandelowski, M. (1991). Telling stories: Narrative approaches in qualitative research. Image: Journal of Nursing Scholarship, 23(3), 161-166.

Smith, J., \& Baltes, P. (1999). Life-span perspectives on development. In M. Bornstein \& M. Lamb (Eds.), Developmental psychology (pp. 47-72). Mahwah, NJ: Lawrence Erlbaum. 


\section{Appendix}

\section{Table 1: Recommendations for Conducting Life Histories With Adolescents}

\begin{tabular}{|c|c|}
\hline Suggestion & Example \\
\hline \multicolumn{2}{|l|}{ Written interview guide } \\
\hline Move in chronological order & $\begin{array}{l}\text { "What was your family like when you were little } \\
\text { (in elementary school, middle school, high school)?" }\end{array}$ \\
\hline Include important life contexts & $\begin{array}{l}\text { "Tell me about your family (friends, school, activities). } \\
\text { Who lived with you? How was it in your home?" }\end{array}$ \\
\hline Include many follow-up questions & $\begin{array}{l}\text { "Can you tell me more about that? Give me an } \\
\text { example." }\end{array}$ \\
\hline Include open-ended questions & "Tell me about your plans and dreams for the future." \\
\hline Be flexible & $\begin{array}{l}\text { Develop new questions if needed; use prompts and } \\
\text { cues } \\
\text { to elicit details, perceptions, and emotional responses }\end{array}$ \\
\hline \multicolumn{2}{|l|}{ Interviewing } \\
\hline Schedule multiple 1-hour interviews & $\begin{array}{l}\text { Schedule the first interview at the time of consent and } \\
\text { the } \\
\text { second immediately after the first }\end{array}$ \\
\hline Make reminder phone calls & Confirm the night before or day of the interview \\
\hline $\begin{array}{l}\text { Reserve sensitive questions for the } \\
\text { second interview }\end{array}$ & $\begin{array}{l}\text { Topics include sexuality, family discord, and } \\
\text { substance use }\end{array}$ \\
\hline $\begin{array}{l}\text { Meet at a place convenient for the } \\
\text { teen }\end{array}$ & Examples include school, community center, or clinic \\
\hline Arrange transportation & $\begin{array}{l}\text { Provide bus tickets; ask parent to transport teen; meet } \\
\text { at a } \\
\text { time that does not interfere with the teen's usual way } \\
\text { home }\end{array}$ \\
\hline \multicolumn{2}{|l|}{ Life history grid } \\
\hline $\begin{array}{l}\text { Consider completing during the } \\
\text { interview }\end{array}$ & $\begin{array}{l}\text { This is a way of engaging the participant in the } \\
\text { research process }\end{array}$ \\
\hline Add details during analysis & $\begin{array}{l}\text { This is a useful way of diagramming life patterns } \\
\text { concisely }\end{array}$ \\
\hline Give a completed copy to participant & $\begin{array}{l}\text { This enhances the experience as a research } \\
\text { participant }\end{array}$ \\
\hline
\end{tabular}


Table 2: Example of a Portion of a Life History Grid

\begin{tabular}{|c|c|c|c|c|c|c|c|c|c|c|}
\hline Year & Age & Parents & Siblings & Geography & Friends & School & Activities & Health/Puberty & Romance & Church \\
\hline 1983 & 0 & $\begin{array}{l}\text { Parents not } \\
\text { married }\end{array}$ & & $\begin{array}{l}\text { Living in } \\
\text { Arkansas with } \\
\text { maternal } \\
\text { grandmother }\end{array}$ & & & & & & $\begin{array}{l}\text { "Grew up" in } \\
\text { Baptist } \\
\text { church }\end{array}$ \\
\hline $1984^{a}$ & 1 & $\begin{array}{l}\text { Mom marries } \\
\text { stepfather }\end{array}$ & $\begin{array}{l}\text { Maternal } \\
\text { sister born }\end{array}$ & $\begin{array}{l}\text { Lived in a small } \\
\text { community }\end{array}$ & & & & & & \\
\hline $1987^{a}$ & 4 & & $\begin{array}{l}\text { Maternal } \\
\text { brother } \\
\text { born }\end{array}$ & & & & & & & \\
\hline $1989^{a}$ & 6 & $\begin{array}{l}\text { Decreased } \\
\text { contact with } \\
\text { birth father }\end{array}$ & & & & $\begin{array}{l}\text { Grades } \\
\text { kindergarten } \\
\text { through } 5 \text { in } \\
\text { Arkansas }\end{array}$ & & & & $\begin{array}{l}\text { Stole } \\
\text { something, } \\
\text { G'mo scared } \\
\text { her with hell, } \\
\text { never stole } \\
\text { again }\end{array}$ \\
\hline 1994 & 11 & $\begin{array}{l}\text { Dad stops } \\
\text { calling; more } \\
\text { fighting with } \\
\text { mom }\end{array}$ & & & & $\begin{array}{l}6^{\text {th }} \text { grade in a } \\
\text { "prejudiced } \\
\text { school," fails } \\
6^{\text {th }} \text { grade }\end{array}$ & & Menarche & & \\
\hline 1995 & 12 & & & $\begin{array}{l}\text { Move to a new } \\
\text { town in } \\
\text { Arkansas with } \\
\text { mother and } \\
\text { siblings }\end{array}$ & & $\begin{array}{l}\text { Repeats } 6^{\text {th }} \\
\text { grade at new } \\
\text { middle school, } \\
\text { continues } 7^{\text {th }} \\
\text { and } 8^{\text {th }} \text { grades } \\
\text { there }\end{array}$ & $\begin{array}{l}\text { Plays } \\
\text { trumpet }\end{array}$ & $\begin{array}{l}\text { Misses a period } \\
\text { and has two } \\
\text { pregnancy scares }\end{array}$ & $\begin{array}{l}\text { Kisses a boy } \\
\text { (no } \\
\text { intercourse) }\end{array}$ & \\
\hline
\end{tabular}


Table 2 (continued)

\begin{tabular}{|c|c|c|c|c|c|c|c|c|c|c|}
\hline Year & Age & Parents & Siblings & Geography & Friends & School & Activities & Health/Puberty & Romance & Church \\
\hline 1998 & 15 & & & Arkansas & & $\begin{array}{l}\text { Freshman: } \\
\text { loves sports } \\
\text { and plays on } \\
\text { three teams }\end{array}$ & $\begin{array}{l}\text { Debate, FBI, } \\
\text { Home } \\
\text { Economics } \\
\text { Club, job at } \\
\text { plastic sign } \\
\text { company }\end{array}$ & & First "love" & \\
\hline 1999 & 16 & $\begin{array}{l}\text { Mother and } \\
\text { stepfather } \\
\text { divorce }\end{array}$ & & & $\begin{array}{l}\text { Fights girl } \\
\text { at school } \\
\text { who } \\
\text { harasses } \\
\text { her }\end{array}$ & $\begin{array}{l}\text { Sophomore: } \\
\text { suspended } \\
\text { twice }\end{array}$ & $\begin{array}{l}\text { Continues } \\
\text { success in } \\
\text { activities }\end{array}$ & & & $\begin{array}{l}\text { Trip to } \\
\text { New } \\
\text { York with } \\
\text { church }\end{array}$ \\
\hline 2000 & 17 & $\begin{array}{l}\text { Birth father } \\
\text { calls: teen } \\
\text { not ready to } \\
\text { open up }\end{array}$ & $\begin{array}{l}\text { Best } \\
\text { friends } \\
\text { with sister }\end{array}$ & $\begin{array}{l}\text { Moved to } \\
\text { Wisconsin for } \\
\text { mother's } \\
\text { remarriage, } \\
\text { which does } \\
\text { not happen }\end{array}$ & $\begin{array}{l}\text { Has lots of } \\
\text { friends: } \\
\text { does not } \\
\text { know if } \\
\text { they are } \\
\text { abstinent }\end{array}$ & $\begin{array}{l}\text { Junior: plays } \\
\text { four sports }\end{array}$ & $\begin{array}{l}\text { Newspaper, } \\
\text { band, church } \\
\text { choir }\end{array}$ & $\begin{array}{l}\text { "Now I'm back to } \\
\text { tomboy" }\end{array}$ & $\begin{array}{l}\text { Boyfriend for } \\
\text { past } 2 \text { years: } \\
\text { he is in } \\
\text { college }\end{array}$ & $\begin{array}{l}\text { In church } \\
\text { choir }\end{array}$ \\
\hline
\end{tabular}

a. The years $1985,1986,1988$, and 1990 to 1993 were not included because of limited data.

b. $\mathrm{FBL}=$ Future Business Leaders. 